by the gland tissue, very much as in sphæriaceous fungi the cavity of the perithecium is lined by asci. But even in this they agreed with the lid glands noticed by Dickson in $N$. levis, and termed by him "perithecioid." Careful study of the outer lid surface revealed a few similar glands. On comparison of the species and hybrids grown in the Royal Botanic Garden, Edinburgh, a like condition was found to occur in all. The presence of these on the outer pitcher surface of $N$. ampullaria is interesting, since in it the lid is rudimentary, directed back, and destitute of glands on its inner surface.

At Prof. Dickson's suggestion I then examined the expanded lamina, and was agreeably surprised to find that glands were scattered rather sparingly over its upper, but pretty abundantly over its under, surface, especially near its junction with the stem. The tendril intervening between the lamina and pitcher also possessed them, and in some cases they were of very large size. Passing to the stem, it was found that some spccies had them very sparingly, others in considerable number, but while resembling those on the leaf externally, they were sunk much deeper in the tissue of the cellular layer, and strikingly reminded one of a simple animal gland.

After a comparative study of the different species I was induced to look at the sepals, as our garden curator, Mr. Lindsay, had mentioned to me that a very copious secretion of nectar took place in flowering. A complete pavement of glands the same in size and appearance as those on the inner lid surface of the pitcher, was spread over the upper epidermis of each. In Hooker's elaborate monograph of the genus ("De Cand. Prod.," vol. xvii.) these are mentioned, though their complete resemblance to the latter is not indicated. A few large "peritheicoid "glands may also be seen on the lower epidermis, and in flowers of $N$. bicalcarata (for opportunity of examining which I am indebted to $\mathrm{Mr}$. Courtauld of Braintree), these attain relatively a gigantic sice.

We see, therefore, that in Nepenthes, with its diocious flowers, the sane structure, which by their secretion attract insects for aiding in fertilisation, also lure them to the pitcher, so that their dead bodies may help in the nutrition of the plant.

Sarracenia.-Mellichamp pointed out (Cardener's Chronicle, 1874) that honey-glands are present not only on the lid, but also on the external projecting wing of the pitcher. I find, however, that, as in the last genus, they are diffused over the whole outer surface, including the lid; further, that in some of the species $(S$. vario'aris and $S$, rubra there are external upward directed hairs, as in some of the Nepenthes. On the outer surface of the three bracteoles and of the sepals the glands are likewisc numerous, and will undoubtedly be insect attractors for promoting cross-fertilisation.

Darlingtomia.--This genus agrees with the last, except that the glands are very simple, being one- or at most two-celled. I have not as yet examined the flower, though there can be little doubt but that in it a like condition will occur.

Cephalotus.-.-Prof. Dickson, in studying this genus, noticed glands not only on the lid and outer pitcher surface, but even on the ordinary foliage leaves. I therefore required to deal only with the flowers. Scattered among the "encapsulating" hairs on the peduncle, bracts, and six sepals, were many glands identical with those of the leaves, though rather smaller; but further, the peculiar glandular processes intervening between the stamens and carpels seem to be the same mounted on cellular outgrow ths of the receptacle.

Nepenthes, Sarracenia, Darlingtonia, and Cephalotus are therefore found to agree fundamentally in their morphological arrangements for physiological purposes, though referable to orders widely separated systematically.

Botanical Laboratory, University of Edinburgh

\section{Earthquakes in England, and their Study}

As no record of the most recent earthquake shock in England has yet found a place in the pages of NATURE, perhaps I may be permitted to give the following slight details, collected from the daily papers of Lancashire and London for November 15 :A shock of carthquake ("severe," yet causing no actual injury) was cxperienced at Clitheroe, and in the neighbourhood, on the evening of November 14. At about 5.Io p.m. a terrific report, rescmbling loud thunder, was heard, instantly followed by a strong vibration of the earth, sufficient to induce the inhabitants to run out of their houses into the streets in a terrified state.
At Low Moor, where the shock seems to have been felt most strongly, the wife of a man named Wilkinson fainted with fright. A waggoner on the road states that his two horses were nearly thrown to the ground. Much excitement prevailed throughout the borough and neighbourhood of Clitheroe, especially at Low Moor.

A lurid glare noticed in the sky at the time of the disturbance -5 . Io p.m., sun set at 4. Io-is mentioned in connection with the occurrence, but that appearance was, in all probability, only one of the sunset-glow effects with which we have lately bccome so familiar, and had nothing to do with the shock.

The circumstance that this particular part of Lancashire is much subject to earthquake disturbances, makes it specially important that no details of their occurrence be lost to science. Within the last fifty years at least six well-authenticated shocks have been recorded, -in 1835, 1843, I868, 1871, 1873, and 1884, - and this list might easily be extended. Lancashire, indeed, may be considered as one of the chief areas of disturbance in England, and after Comrie, in Perthshire, perhaps the most important centre of seismic action in Great Britain.

While writing upon this subject, perhaps I may be allowed to offer the suggestion that, as the study of seismology is now one of such growing importance, it would be of considerable interest to many if a small space were set apart in the columns of NATURE every month, devoted specially to the record of ctrrent earthquake action, and kindred convulsions, in a scientific manner. It is my experience, as one who has for some time been engaged in collecting certain facts of these phenomena from varions sources, that no sufficiently precise and complete records of the necessary facts, as may thus be readily transferred to the annals of exact science, are anywhere available. The general observations of seismic disturbance as heretofore described, are usually not only scanty in the matter of their detail, and often dressed up still with a superstitious flavouring, but also, for lack of the right class of observation, are too frequently merely vague and useless statements of wrong facts, generally in favour of doubtful hypotheses; and these are allowed to take the place of a well-ordered treatment of the real state of the case, upon a proper scientific basis.

55, Highbury Hill, N., December 9

\section{The Cacao-Bug of Ceylon}

THE note by Mr. Distant in your number for October 30 ( $p$. 684) may perhaps lead its readers to think that the insect which has lately been the subject of a report to the Ceylon Government has been wrongly identified by me as Helopeltis antonii, Sign. As that report will, however, before this have reached England, the matter will probably have been set right. I am not an entomologist, nor have I here the opportunity of reference to Signoret's original description or to other descriptive works; but the insect is, without any doubt at all, that which is well known-too well known-in Assam and in Java as Helopillis. In the former country it is the destructive tea-bug or "mosquito-blight," I and in the latter it is the notorious pest of the cinchona plantations.

As to the fragments which reached Mr. Distant, they were apparently insufficient for identification, further than with the family Reduviida. The cacao-tree harbours a host of Hemiptera, and planters are very apt to confound the innocent with the guilty. Its only formidable encmy in this order of insects, however, so far as I have seen, is the Helopeltis.

Royal Botanic Garden, Pcradeniya, Ceylon, HENRY TRIMEN November $2 \mathbf{t}$

\section{The "Messenger of Mathematics"}

I THINK it is right that attention should be publicly directed to the exceedingly irregular appearance of the Messenger of Mathematics. In the case of a magazine of its size and character there is no reason whatever why it should not be published on the first of each month. The "heavy" mathematical journals may be permitted to turn up when their editors please; but the case of a monthly meant to foster a taste for mathematical investigation among junior mathematicians is entirely different; incleed, the good such a magazine is calculated to do is almost nullified by irregular publication. The Messenger is always

2 Since my report was written, Mr. Wood-Mason's short treatise on the ea-bug has reached us here. 